\title{
Forgoing the architect's vision: American home economists as pioneers of participatory design, 1930-60
}

Anna Myjak-Pycia

The phenomenon of participatory architectural design is thought to have emerged in the late 1960 s and 1970 in Europe. In 1969, Giancarlo De Carlo, one of its main advocates, presented a manifesto in which he asserted that 'architecture is too important to be left to architects', criticised architectural practice as a relationship of 'the intrinsic aggressiveness of architecture and the forced passivity of the user', and called for establishing 'a condition of creative and decisional equivalence' between the architect and the user, so that in fact both the architect and the user take on the architect's role. He also argued for the 'discovery of users' needs' and envisioned the process of designing as planning 'with' the users instead of planning 'for' the users. ${ }^{1}$ In the same year, De Carlo began working on a housing estate in Terni, Italy that involved future dwellers in design decisions. Among other participatory projects carried out around that time were Lucien Kroll's medical faculty building for the University de Louvain (1970-6) and Ottaker Uhl's Fesstgasse Housing, a multi-storey apartment block in Vienna (1979).

Explicitly opposing the modernist movement, the proponents of participation not only wanted the user's greater involvement in the design process, but

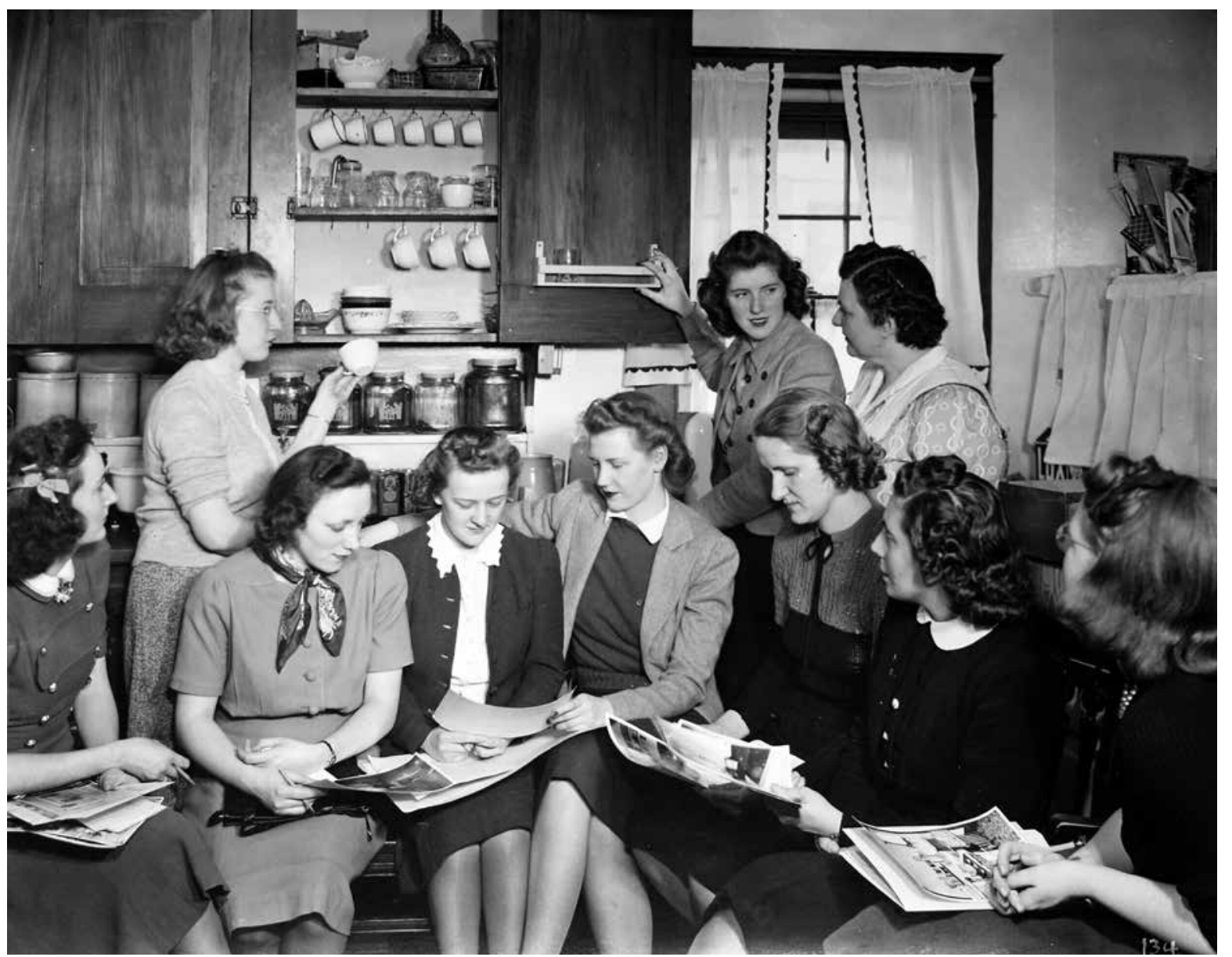

Cornell University home economics

students gathered in the kitchen of an Ithaca homemake who explained to them her kitchen's problems, 1940. The meeting was one of the preliminary steps in the project of remodelling the kitchen. During the meeting, the students measured both the room and the kitchen's objects. Dept. of Household Economics and Management Research Studies, Division of Rare and Manuscript

Collections, Cornell University Library, \#23-18-1648, Box 5 . 
also called for defining the user in a more specific way. Accusing modernists of adhering to a universal notion of the human being, they proposed thinking about users of architecture more in terms of types, groups consisting of people sharing concrete social conditions. In their view, the improved architectural planning entails a direct participation of users and 'an identification of needs requires the concrete presentation of those who have them'.'

Kindred in spirit was the phenomenon of the post-occupancy evaluation (POE), a field concerned with processes and procedures aiming at a rigorous assessment of buildings after they have been built and used for some time. ${ }^{3}$ It emerged in the 1960 s both in the United States and the United Kingdom. The evaluation methodologies measured the performance of buildings in terms of the mutual relationship between people and their environment. One pillar of the assessment examined the building's impact on users, taking into account their viewpoint and needs, for example how the building scored regarding its purpose, functionality, and comfort. The other pillar ascertained the occupants' impact on the building, for example how it performed technically, economically, and in the realm of energy consumption. ${ }^{4}$ Among the evaluation's goals has been both to improve specific buildings by identifying problems that require solving, and, through the generalisation of the collected data, to contribute to design criteria for the architectural profession. ${ }^{5}$ The belief that the post-occupancy evaluation conveyed was clear: to create better architecture in the future, taking into account the building's performance in usage, and from the user's point of view, is necessary.

The accepted narrative of the 1960 and 1970 s as the emergence of participation in design is undermined by records from the home economics collections in the archives of Cornell University and Purdue University, which show indisputably that already in the 1930s American home economists practiced many of the tenets that De Carlo, Kroll, and the post-occupancy evaluation started voicing and realising in the 1960s. Keeping the user involved at every stage of design, conforming as much to the user's bodily dimensions as to her preferences, and giving the user the ultimate say regarding the design's development, home economists' design practice effectively enacted the model of planning with the user.

The American home economists' practice not only preceded the participatory manifestos and projects of the 1960 and 1970 and the postoccupancy evaluation, but also worked out an original method of carrying it out that differed from them. The participatory projects that have been developed since the 196os and 1970s usually have had either of two characteristics. Future dwellers have been admitted to the discussions and decisions regarding the organisation of space, but the process has been conducted with the help of typical architectural devices: plans and a significantly scaled-down model of the building. For example, for the purpose of Wohnregal (1986), Klejj Nylund and Peter Stürzebecher conducted consultations with future dwellers with the aid of a 1:20 model; at Byker in Newcastle upon Tyne Ralph Erskine worked with future inhabitants via plans. ${ }^{6}$ Of course, the very use of intensely scaled-down models and plans has been an imposition of the architect's professional means of spatial thinking on the user unaccustomed to it, which made it difficult to create a balanced architect-user collaboration towards which the movement of participation aspired.

Secondly, many of the participatory projects carried out within the movement of participation that started in the 196os have not relied on an intense, direct architect-future dweller exchange and collaboration. Frequently, the user's involvement occurred mainly after the architect left off: the architect accounted for the user primarily by setting the stage for him or her - intentionally making the building incomplete to let users fill it with their solutions - as was the case in Herman Hertzberger's Diagoon Houses (1971). Engaging in the design within such a consecutive arrangement, the dweller had as much hegemony over the space as it was preconceived by the architect who delineated the limits of the dweller's freedom. An exception to this model of the architect-dweller relationship was Ralph Erskine's redevelopment of the Byker estate at Newcastle upon Tyne (1969-82). Having received the commission for Byker in 1968, Erskine intended to prioritise the preferences of Byker residents in his rebuilding plans. To get to know the residents and gauge what they desired, he opened an office on the site of Byker facilitating them direct access to him. ${ }^{7}$

The method home economists developed succeeded at obviating these two features of the mainstream participatory projects of the 1960 and 1970 , and remained very distinct from the postoccupancy evaluation's procedures that relied largely on data collection via a direct experience of the assessed environment, building performance survey forms, and interviews. Focused on the user as a bodily and mental entirety, home economists designed literally with the user, largely in the same time and space, experimenting with full-scale cardboard replicas of interior spaces. Testing spatial arrangements in a full-scale form facilitated the layman to better understand which of them worked best. In contrast to miniature models that have been such an intrinsic part of the architect's toolset, the full-scale mode of designing enabled a more balanced relationship between the professional and the user, realising in this way one of the main participatory ideals.

\section{Home economics and housing design}

Home economics was a social, reformist movement that emerged in the US at the end of the nineteenth century. Its engagement in domestic design stemmed from its commitment to bringing about changes that would benefit common women: the movement's mission 'the betterment of the 

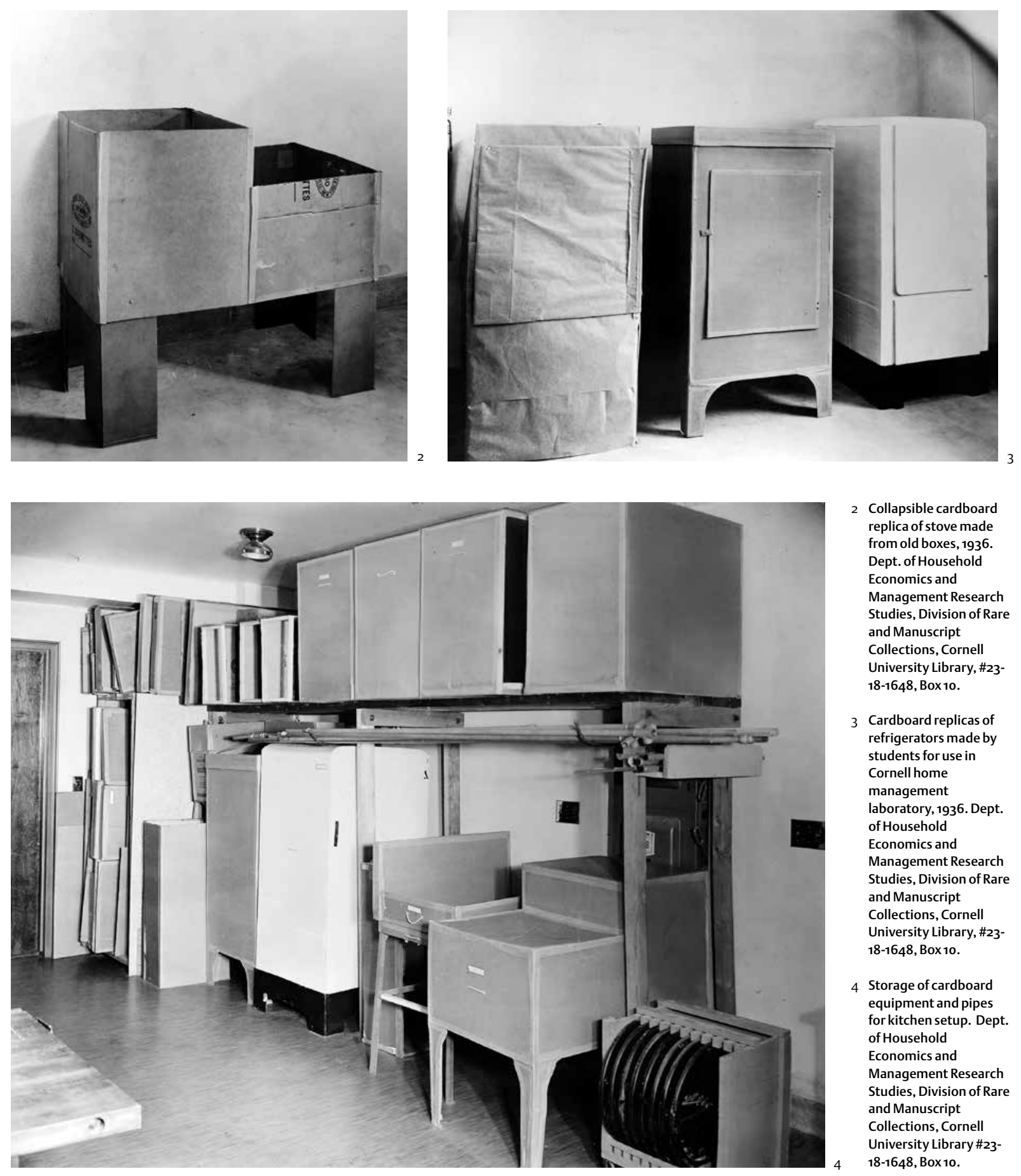
2 Collapsible cardboard replica of stove made from old boxes, 1936. Dept. of Household Economics and Management Research Studies, Division of Rare and Manuscript Collections, Cornell University Library, \#23- 18-1648, Box 10 .
3 Cardboard replicas of refrigerators made by students for use in Cornell home management laboratory, 1936. Dept. of Household Economics and Management Research Studies, Division of Rare and Manuscript Collections, Cornell University Library, \#23- 18-1648, Box 10.
4 Storage of cardboard equipment and pipes for kitchen setup. Dept. of Household Economics and Management Research Studies, Division of Rare and Manuscript Collections, Cornell University Library \#23- 18-1648, Box 10.

American home' meant primarily the improvement of living and working conditions of homemakers, whom home economists perceived as main domestic users and workers. A design reform that would make dwelling interiors more accommodating to an average homemaker, in particular more assistive to her everyday labour, was in home economists' view a pivotal step towards this improvement.

The movement developed to a large extent via Land-Grant colleges, which, in addition to the traditional university goals of research and teaching, put an equal emphasis on outreach, offering courses to local rural population. During the first half of the twentieth century, these outreach courses evolved into home economics studies offered at Land-Grant colleges throughout the US. Harnessing the entrenched association of women with domesticity, these programmes offered women a college education that went beyond conventional housekeeping, and involved such subjects as human physiology and chemistry. Through these programmes, home economists succeeded at advancing the professionalisation of American women by helping them become paid experts in various realms of the broadly understood domestic sphere: the college home economics training and degree equipped their alumni with credentials that helped them obtain positions such as teachers, nutritionists, and consumer specialists for industry. ${ }^{8}$ However, even though architects were on the faculty of home economics departments, and architectural topics - such as spatial planning - were a common 


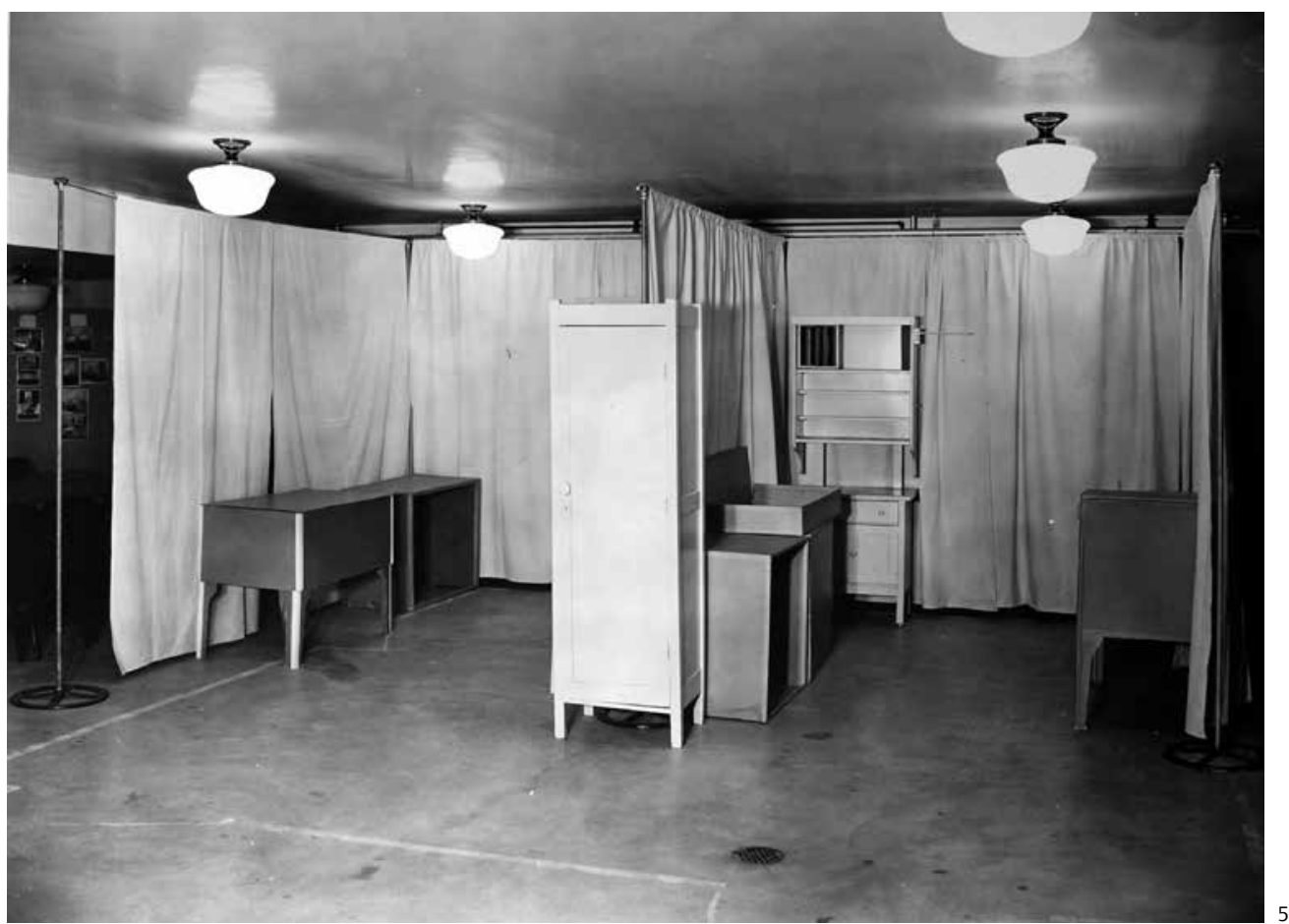

5 Planning work centres in the Cornell home management

laboratory, cardboard duplicates of

equipment and fabric screens as duplicates of walls. Dept. of

Household Economics and Management Research Studies, Division of Rare and Manuscript Collections, Cornell University Library, \#23-18-1648, Box 3. part of home economics curricula, I never came across evidence that college home economics alumni were developing careers as interior designers. Yet, home economics courses played an important role in the movement's design practice in the period between 1930 and 1960.

This design practice can be seen as part of the lineage of American women that worked on relieving an average woman's housekeeping tasks through changes in housing design. For example, in the later nineteenth century various American radical feminists, such as Melusina Fay Peirce and Mary Livermore, advocated for the creation of housing arrangements that accommodated cooperative housekeeping as a way to ease the daily life of women and help them gain economic independence by undertaking paid jobs outside the home. Some of them, like Melusina Fay Peirce, tried to establish such houses and Jane Addams actually succeeded at it. Peirce described the physical features for such cooperative housekeeping dwellings and argued that women architects ought to design dwellings that impose the cooperative model of housekeeping by being kitchen-less. ${ }^{9}$ Although late nineteenthcentury feminists were much more progressive and radical than twentieth-century home economists (who adhered to single-family households with kitchens), both groups were women reformers who shared the conviction that housing is one of the areas through which the women's well-being should be advanced, and engaged in projects that aimed to make this belief a reality.

\section{Home economists' participatory method of design}

The user-centred participatory method of design that home economists practiced is best illustrated via case studies, for example the kitchen remodelling of Mrs Galford (the last name of this homemaker is changed for privacy reasons, as is the last name of the homemaker referenced later in this article). In 1950 , Mrs Galford, a homemaker with a part-time job and a mother of two young children, asked the Cornell Economics of the Household class taught by Ella M. Cushman for help in planning her kitchen. There was nothing strange about this request. As Mrs Galford had already lived in the Ithaca area for many years by then, and her younger sister was at the time a student at the College of Home Economics, she knew that the College's home economists in training, under the supervision of their teachers, were regularly engaged in remodelling projects in local households as part of their coursework. Likely she also realised that although the home economists had ideas of their own about how the home interior should be organised, they would let her have the ultimate say on the final plan.

At the time, the Cornell home economists must have already gained a solid reputation as experts in the realm of domestic interior design at least in the Ithaca area: there were more women interested in having home management students design for them than there were home economists available for such projects. ${ }^{10}$ Mrs Galford, however, did not wait long to have her request met as in October of the same year a group of Cornell students taking the Fall edition of the Economics of the Household 310 gathered in her home to learn about her, her specific living situation, as well as the issues with the kitchen; the interior she wanted to remodel.

After this introduction, during which the students learnt Mrs Galford and her family had been living in the house for about a year, the homemaker invited the students to the kitchen and pointed out its disadvantages. In their reports the students participating in the project recorded a thoughtless arrangement of the kitchen's equipment, for example the isolation of the sink from other working stations due to its location between the doors, the 

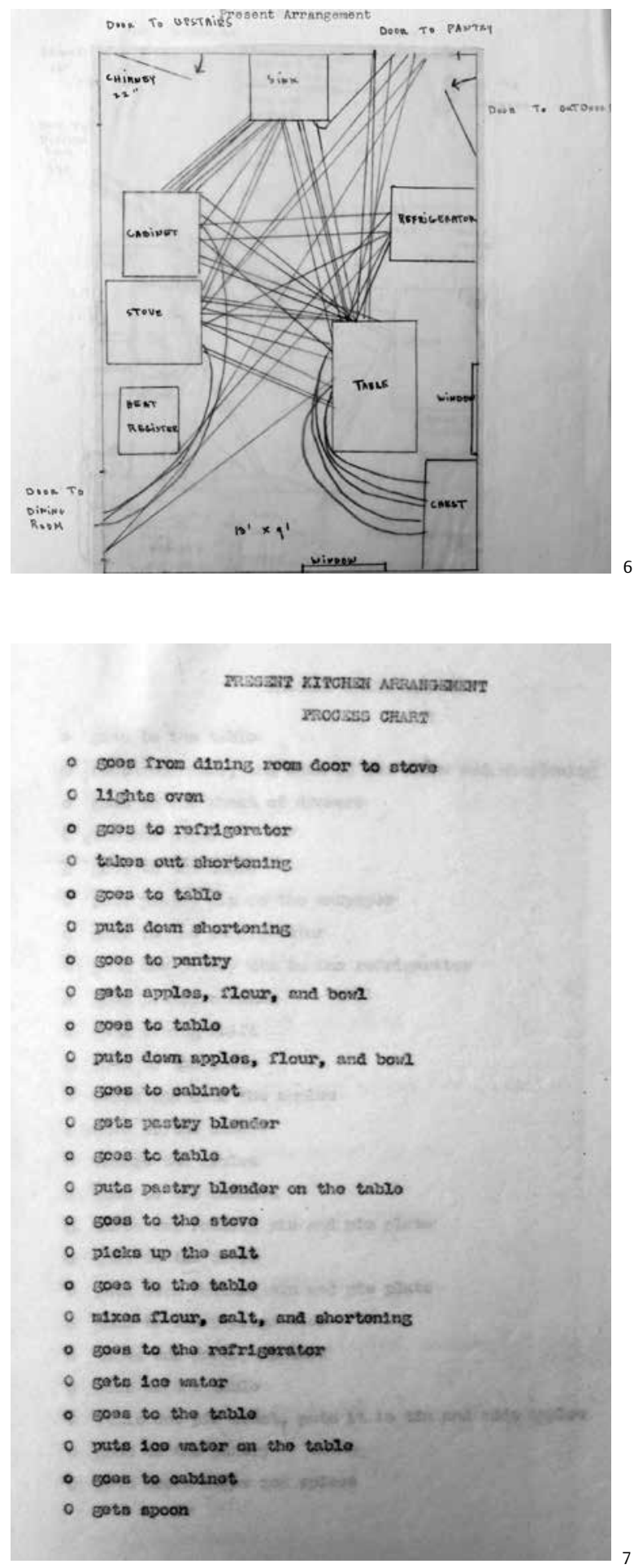

'wrong placement' of the refrigerator given the direction in which its door opens, as well as the virtual absence of counter spaces. ${ }^{11}$ Then, the students took measurements of the kitchen's content to duplicate it to scale in the Cornell home management laboratory. The entire scene must have been similar to the one depicted in a photograph showing a different Ithaca area homemaker in her kitchen working with Cornell students in an analogous situation [1].

The reason for creating a mock-up of Mrs Galford's kitchen in the Cornell laboratory was to enable and assure the homemaker's full bodily engagement in the process of designing her space. To set up the

$\begin{array}{ll}6 \begin{array}{l}\text { 'Flow Chart' for Mrs } \\ \text { Galford's original } \\ \text { kitchen arrangement. }\end{array} & \begin{array}{l}\text { 'Process Chart' for Mrs } \\ \text { Galford's original } \\ \text { kitchen arrangement. } \\ \text { annomemaker was } \\ \text { kept. of Household }\end{array} \\ \begin{array}{l}\text { kitchen: she found it } \\ \text { inconvenient, }\end{array} & \begin{array}{l}\text { Manomics and } \\ \text { Requent }\end{array} \\ \text { requiring too much } & \text { Research Studies, } \\ \text { walking, and lacking } & \text { Manuscript } \\ \text { in storage. Dept. of } & \text { Collections, Cornell } \\ \text { Household Economics } & \text { University Library, } \\ \text { and Management } & \text { \#23-18-1648, Box6, } \\ \text { Research Studies, } & \text { D.J., Term Paper for } \\ \text { Division of Rare and } & \text { E.H., 20 December } \\ \text { Manuscript } & \text { 1950, p. 19. } \\ \text { Collections, Cornell } & \\ \text { University Library, } & \\ \text { \#23-18-1648, Box 6, } & \\ \text { D.J., Term Paper for } & \\ \text { E.H., 20 December 20 } & \\ \text { 1950, p. 18. } & \end{array}$

duplicate, the students used three-dimensional cardboard replicas of kitchen furniture and equipment, held in the lab's storage for the very purpose of constructing such copies of actual household workspaces [2-4]. The walls were represented by curtains held by rods [5].

As the duplicate kitchen was a three-dimensional representation to scale, in terms of physical dimensions, distances, and arrangement, it gave an accurate sense of the original kitchen space. Made from light materials, the duplicate kitchen had an advantage that the original kitchen did not have: portability and the ease of rearrangement. Thus, in this duplicate, the original immobile kitchen was transformed into a workable space, filled with easily interchangeable set of blocks, which invited the homemaker, and the students assisting her, to experiment with alternative arrangements for the kitchen without any hassle and cost involving construction. This experimentation was not an end in itself, but a means to help the homemaker figure out what kind of kitchen plan worked best for her. What she found as the optimal arrangement for her, what felt right to her, was not questioned and became the basis for the actual kitchen's remodelling.

An important part of the homemakers' practical try-outs in the Cornell lab's kitchen duplicates were the so-called 'walk-outs', during which the homemaker enacted her movements during the preparation of a typical meal in a mock-up arranged exactly as her original kitchen and in rearranged plans, which allowed her to compare arrangements. As her 'walk-outs', Mrs Galford enacted the preparation of a meal consisting of steak, baked potatoes, spinach, and apple pie. ${ }^{12}$ Students participating in the projects observed her and recorded her movements both in the form of the so-called 'flow chart', travel lines marked on the kitchen plan, first chalked out on the lab's board and later included in classroom reports, and as the so-called 'process chart', describing the trips and activities in a sequentially organised list [6, 7].

The chart on the board corroborated what Mrs Galford had already told the students: indeed, she did a lot of walking in her kitchen. The chart might have helped her and them, however, to have a better 


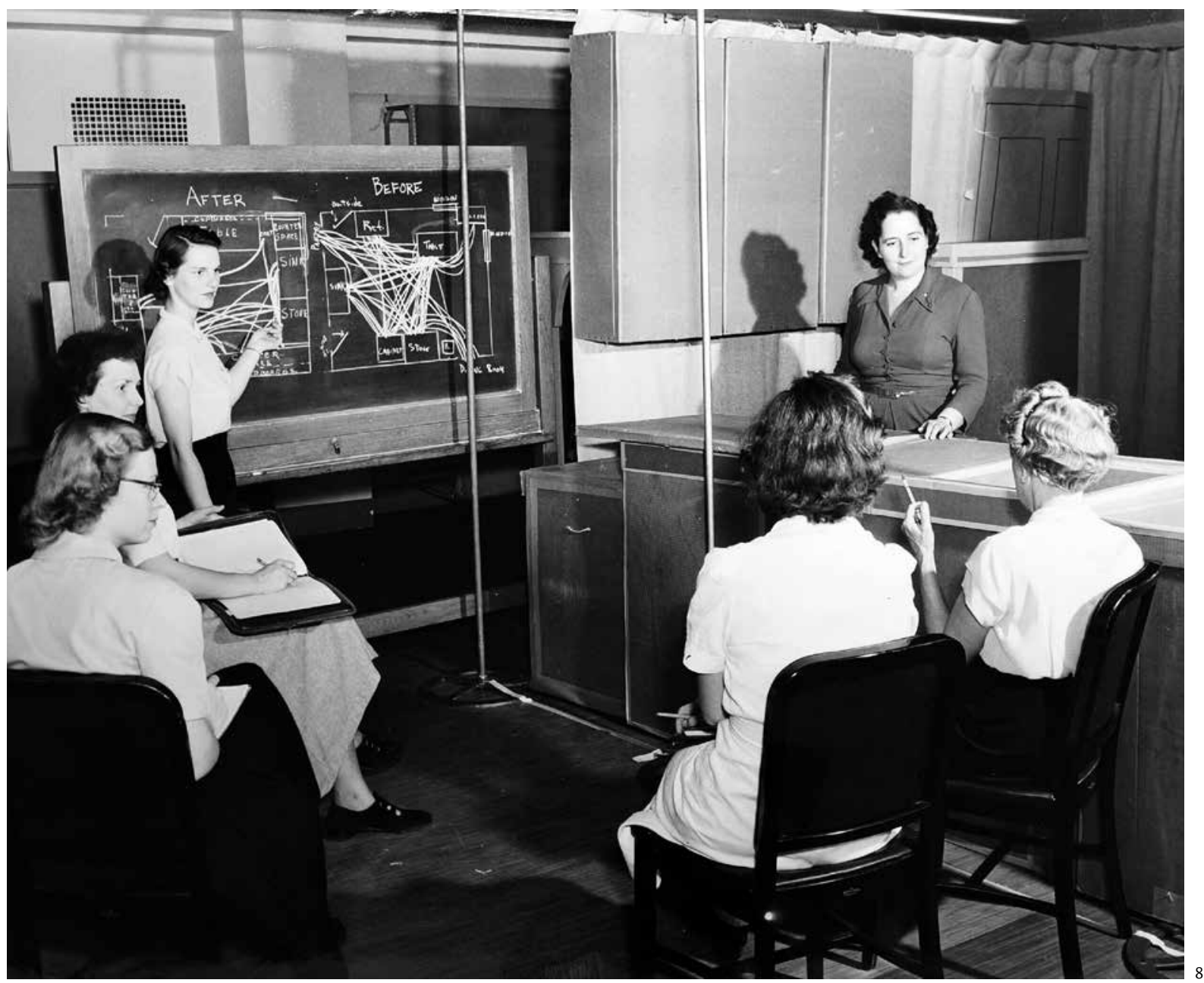

\begin{tabular}{|c|c|c|}
\hline $\begin{array}{l}\text { Mrs Galford and home } \\
\text { economists during } \\
\text { 'walk-out' sessions in } \\
\text { the Cornell } \\
\text { laboratory; on the } \\
\text { board's right is the old } \\
\text { kitchen plan (rotated } \\
\text { ninety degrees } \\
\text { counter-clockwise in } \\
\text { relation to the plan } \\
\text { shown in [6]), on the } \\
\text { left is a proposed plan. }\end{array}$ & $\begin{array}{l}\text { The homemaker } \\
\text { was eager to } \\
\text { improve the kitchen } \\
\text { and at the time the } \\
\text { need was becoming } \\
\text { urgent: she was } \\
\text { pregnant with her } \\
\text { third child, which } \\
\text { meant that in the } \\
\text { years to come she } \\
\text { would become even } \\
\text { more busy, and }\end{array}$ & $\begin{array}{l}\text { likely even more } \\
\text { exasperated by the } \\
\text { kitchen's problems. } \\
\text { Dept. of Household } \\
\text { Economics and } \\
\text { Management } \\
\text { Research Studies, } \\
\text { Division of Rare and } \\
\text { Manuscript } \\
\text { Collections, Cornell } \\
\text { University Library, } \\
\text { \#23-18-1648, Box 10. }\end{array}$ \\
\hline
\end{tabular}

sense of which paths were particularly stepintensive, due to either the paths' length or the frequency of use, or both. This information was a useful indicator of which distances between work stations should be prioritised as the first to be shortened to achieve the reduction of the kitchen mileage requested by the homemaker; assuming, of course, the meal preparation studied was quite representative in terms of the travel pattern it required.

The next step was using the duplicate kitchen to set up a different arrangement for Mrs Galford that she could test in another 'walk-out'. The reports of students who worked on the project leave no doubt that the homemaker's considerations, preferences were the main directives that guided the design process, and that, in addition to shrinking the distances between work stations, the students tried to accommodate Mrs Galford's other wishes.

Mrs Galford's brainstorming meeting with

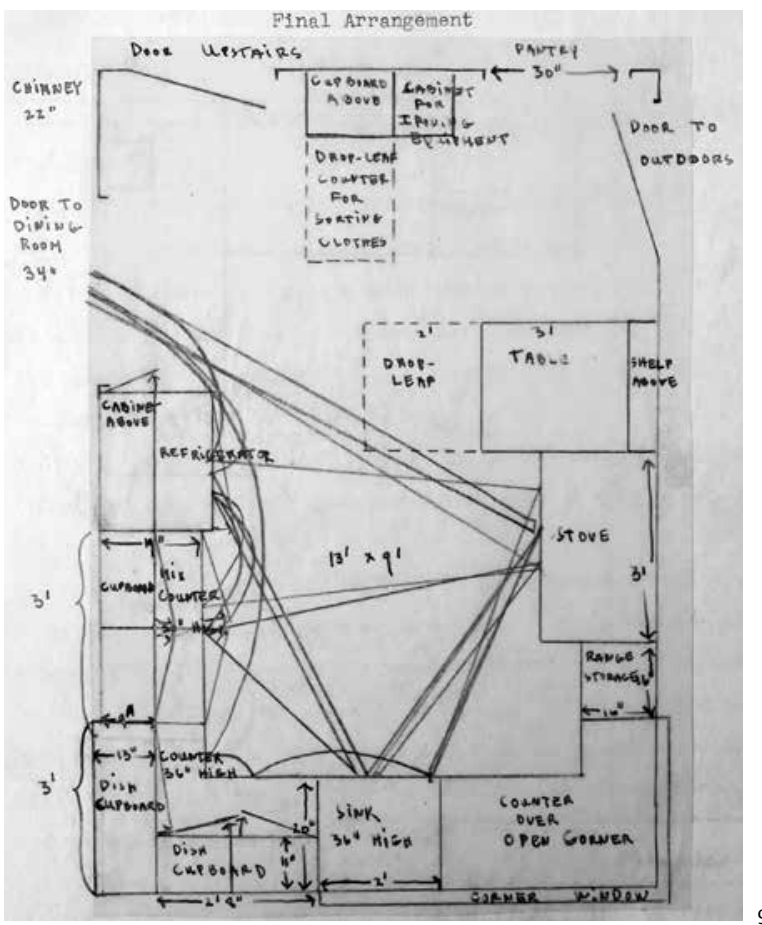

9 Final plan for Mrs Galford's kitchen. Dept. of Household

Economics and Management Research Studies, Division of Rare and Manuscript Collections, Cornell University Library, \#23-18-1648, Box 6 D.J., Term Paper for E.H., 20 December 1950, p. 25. 
students resulted in a 'try-out' arrangement that the homemaker tested by enacting in it the same meal preparation that she did in the original plan. Given Mrs Galford's step-saving goal, the new plan was an improvement, but having taken some time to process it, Mrs Galford was not completely satisfied with it, because she felt that the new plan still did not provide for adequate storage. ${ }^{13}$ With this critique in mind, the students returned to the lab and worked on yet another arrangement that would provide more storage space [8].

Intensely engaging the homemaker, both bodily and mentally, in the remodelling of her space, the Economics of the Household design practice proved to be successful as a boost for the homemaker's spatial initiative, creativity, and boldness. The students working with Mrs Galford conveyed in their reports clearly that the project's process drew her in and that, inspired by the project itself, house design materials, and visits to other households, she not only just posed problems but also developed solutions. It seems that Mrs Galford was coming up with more ideas that the students hoped for: there is a tone of slight annoyance when one of the students reports that when they were almost finished with the kitchen final design, she decided to add a table with a drop leaf at one end. ${ }^{14}$ The plan showing the final arrangement for Mrs Galford's kitchen shows that the table was included [9], which further corroborates that the home economists gave the homemaker the ultimate say regarding the design of her space: the homemaker's wishes were being fulfilled to the very end of the project. According to the students, Mrs Galford was very content with the final plan. The fact that the completed project remained close to the final arrangement worked out by the Economics of the Household students and the homemaker testifies to her satisfaction even further.
The plan also stood the test of time, as the actual remodelling construction took almost three years.

A deviation from the final plan was moving the table from the middle of the room to the room's corner below the widows [10]. One can be quite certain, however, that although the table's relocation to the kitchen's window corner brought about a spatial pattern that fulfilled home economists' theoretical tenets of the ease of movement and reach, the shift resulted primarily from Mrs Galford's individual preferences, rather than a blunt attempt to realise the home economists' theory in physical space. As it was discussed earlier, when Mrs Galford asked for help of the Economics of the Household class in the remodelling of her kitchen, she clearly wanted the kitchen to be labour saving. But it quickly became evident that practicality was not the only thing on her mind. Having gone into the details of her wishes for the room, she conveyed to the students her desire for the relocation of windows towards the kitchen's corner for a reason that had nothing to do with the efficiency of housework: she very much liked the mountain view to which the corner was directed, and wanted windows that would enable her to enjoy the hilly vista. Installing such windows in Mrs Gaford's kitchen was an invasive and labour-intensive change, requiring piercing large openings in the house's external walls, so the fact that she was willing to take the hassle and cost of such a messy remodelling testifies to her fondness for the idea of having the window view. Given that fondness, it is very likely that the table's shift to the window corner was initiated by Mrs Galford's determination to provide more opportunities to enjoy the view: in this corner location, one could admire the view while sitting at either of the table's two outward-facing sides. This

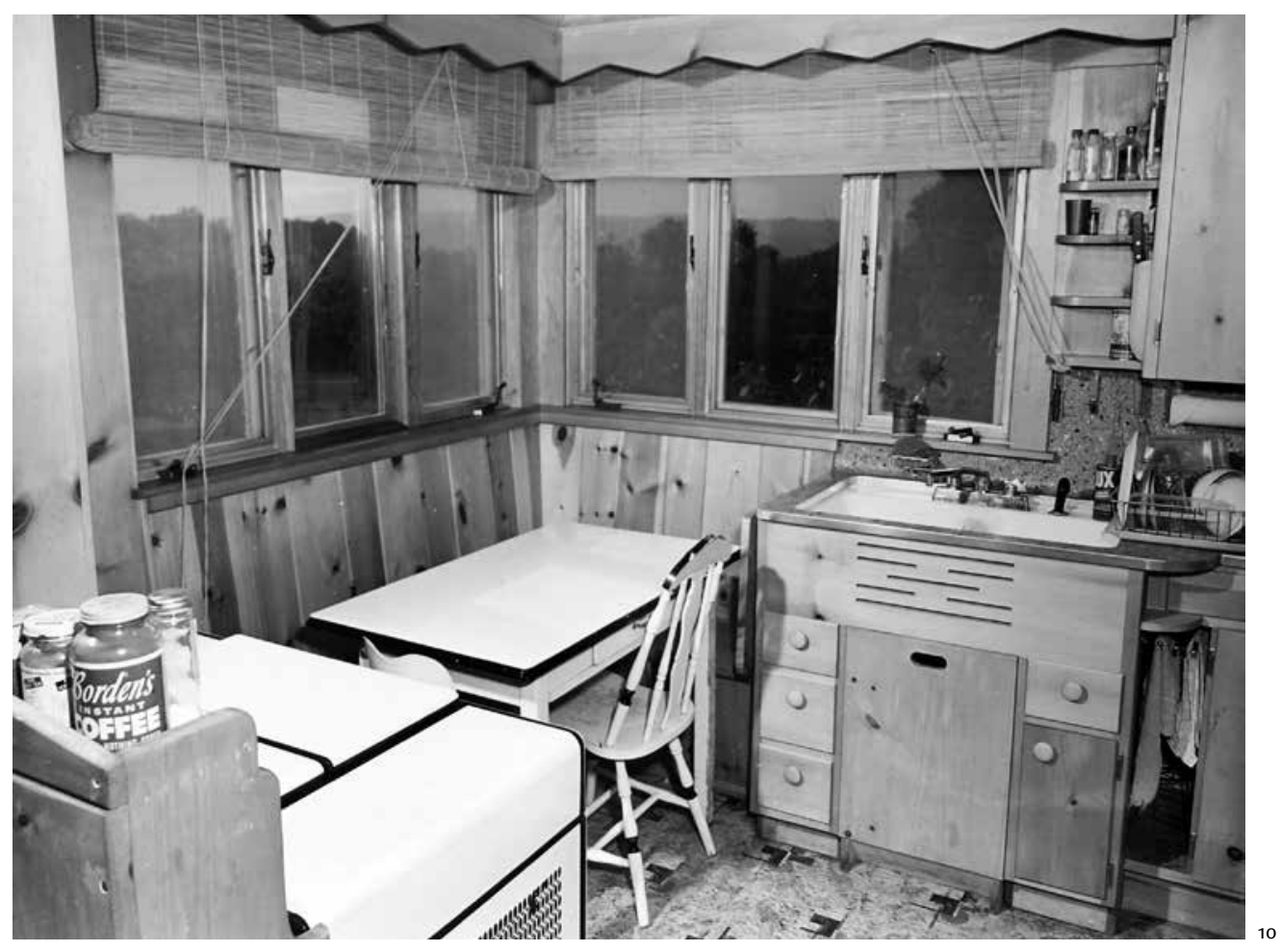

Mrs Galford's kitchen after the remodelling. The completed project included few deviations from the final plan [9]: moving the table from the middle of the room to the room's corner below the widows, shifting the stove from its location along the wall to the place occupied by the table on the plan, and forgoing the counter below the widows. Dept. of Household Economics and Management Research Studies, Division of Rare and Manuscript Collections, Cornell University Library \#23-18-1648, Box6. 

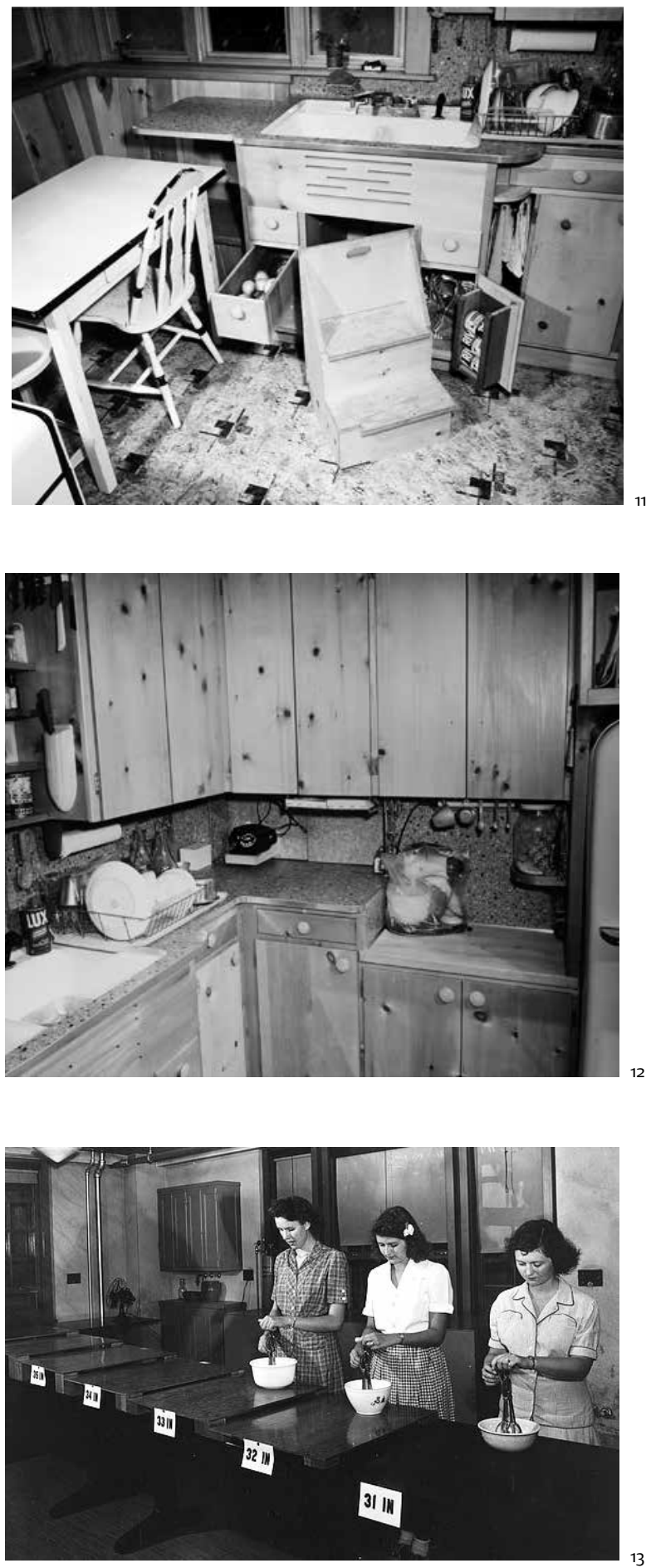

11 Mrs Galford's

kitchen after the remodelling. Sink area. The counter section to the sink's left can be folded as needed. Dept. of Household Economics and Management Research Studies, Division of Rare and Manuscript Collections, Cornell University Library, \#23-18-1648, Box 6.

$\begin{array}{ll}12 \text { Mrs Galford's } & \text { 13 Cornell students } \\ \text { kitchen after the } & \text { testing correct } \\ \text { remodelling. Two- } & \text { heights for work } \\ \text { level countertop. } & \text { surfaces, 30 July } \\ \text { Dept. of Household } & \text { 1943. Mrs Galford } \\ \text { Economics and } & \text { must have used } \\ \text { Management } & \text { similar ones when } \\ \text { Research Studies, } & \text { she came to the } \\ \text { Division of Rare and } & \text { Cornell laboratory. } \\ \text { Manuscript } & \text { Dept. of Household } \\ \text { Collections, Cornell } & \text { Economics and } \\ \text { University Library, } & \text { Management } \\ \text { \#23-18-1648, Box6. } & \text { Research Studies, } \\ & \text { Division of Rare and } \\ & \text { Manuscript } \\ & \text { Collections, Cornell } \\ & \text { University Library, } \\ & \text { 23-2-749, item } \\ & \text { \#DD-HEM-48. }\end{array}$

meant, for example, that the time of consuming meals could be accompanied by the pleasure of looking at the scenery.

It is also possible that Mrs Galford realised that there was at least one more advantage of providing for sitting in the window corner's kitchen area: enabling and encouraging to look in the far distance for a prolonged time, the corner was taking on the quality of expansiveness that to a degree counterbalanced the dominant compactness, tightness of the kitchen's arrangement. It was a zone for a time of farsighted respite from all the close-by objects that imposed a lot of looking at a short distance. The area might have protected the kitchen's user from claustrophobic feelings: the testing 'walkouts' in the Cornell lab duplicate kitchen might have made Mrs Galford aware of the possibility of such sensations in the close-fitted environment and might have steered her thinking towards obviating the risk of experiencing a sense of entrapment.

\section{Home economists' kitchen versus modernist kitchen}

The home economists' participatory method offered a constructive alternative to the mainstream modernist approach to domestic design. In doing so, it fulfilled one of the crucial tenets of participation expressed later in the 1960s and 1970s, namely the rejection of the typical modernist model of designing, in which architects imposed their vision on the user. This constructive alternative is evident in the case of Mrs Galford's kitchen remodelling discussed above.

Interestingly, to some extent the effect of Mrs Galford's window corner was reminiscent of many mainstream modernist buildings: with the aid of generous wall openings and glass in the upper part of the adjacent walls, the upper part of the corner and the Ithaca landscape outside created the impression of continuity; visually, the windows took the hills in. Yet, it was just the upper part of the kitchen's corner. The corner's base remained clearly defined. The rest of the kitchen was the opposite of expansiveness: a tight setting with very little room to roam both for the eyes and the entire body. Nothing of the transparency, the sparseness of objects, and the pervading sense of vacuum present in, for example, Ludwig Mies van der Rohe's Farnsworth House, whose design and construction, taking place in the years $1945^{-} 51$, overlapped in time with the remodelling of Mrs Galford's kitchen.

Mrs Galford's kitchen and Farnsworth House remain very different from each other also when one compares the design processes that led to the projects' creation. The kitchen project was from the start a development in which Mrs Galford not only participated intensely and directly, but was also given the last say regarding the plan and its realisation. It was an example of design practice that is very user-centred, focused on catering to the user's wishes through her bodily and mental engagement in the design process. Consequently, it was design practice in which the user's privileged position overshadowed the designer's status: the designer, the team of Cornell home economists in training, was 
just an understated helper in the service of the userclient. In short, it was design practice that, due to its emphasis on the user, was predisposed to bring about an architectural project with which the user identified as her own and which she recognised as suited for her, a combination of what she found practical for herself and what she just liked.

By contrast, Farnsworth House, although commissioned as a liveable weekend home quickly turned out to be primarily Mies van der Rohe's project in which the client, Edith Farnsworth, was relegated to the role of a repressed and silenced patron who financed the entire enterprise, but was excluded from any significant impact on the shape it took. Even though Farnsworth had a clear idea of what kind of house she wanted, the architect did not feel obliged to respect her wishes and never sought her approval for his plans, even for his most unconventional solutions, such as transparent glass walls. Mies's authoritarian hold over the design process resulted in a project that was primarily a reflection of the architect's views on architecture, his understanding of architecture as a matter of mainly semantics and aesthetics. In designing this showpiece of architectural minimalism, Mies's ambition was to create an environment conducive to spirituality. Believing in beauty as a source of revelation, he designed the house as primarily a space to contemplate the beauty of the surrounding landscape. Accommodating the practicalities of his client's use of the home did not interest him. ${ }^{15}$ Unsurprisingly, Farnsworth became an unhappy dweller in the house.

After the two projects were completed, a telling difference between the kitchen in the Farnsworth House and that of Mrs Galford's was the shape of the countertop. Farnsworth's kitchen countertop was a modernist staple that at the time of the house's construction was already established as a dominant feature of American kitchen design that connoted modernity: it was the classic continuous countertop that seamlessly banded all appliances in a rigorously straight horizontal surface, still very popular today. ${ }^{16}$ By contrast, the countertop in Mrs Galford's kitchen was neither that long and fixed, nor unrelentingly at the same height. Its only fixed part was on the right of the sink, whereas its counterpart on the sink's left side could be either folded or unfolded as needed [11]. The fixed section on the sink's right was divided into two levels: the higher level was an extension of the sink's upper edge, whereas the lower one was the surface of the mixing station [12].

The two-level countertop in Mrs Galford's kitchen was by no means arbitrary. Closely following the home economists' theory of domestic design, it was a result of careful measurements of Mrs Galford's bodily comfort when she imitated her kitchen activities, such as reaching for objects, mixing, etc., and her wishes. ${ }^{17}$ To establish comfortable heights, a student notes that Mrs Galford took advantage of the different testing tables, designed for that particular purpose, in the Cornell lab [13]. ${ }^{18}$ Having taken into account the measurements, the frequency of use of different objects, as well as Mrs Galford's wishes, the students worked out a design of the mix centre. The height of the counter of the mix centre was planned to be 30 inches high and 19 inches deep, because these dimensions turned out to be optimal for Mrs Galford during her activities at this work station.

There is an irony in the difference between Farnsworth's and Mrs Galford's projects. Farnsworth, an independent, wilful, professionally successful, and financially secure woman, who spent on the house much more money than the cost of an average house at the time in the US, and more than it was originally estimated, did not manage to establish a collaboration with her architect that would give her a decisive impact on the house. By contrast, Mrs Galford, an average homemaker of modest financial means, enjoyed the privilege of full participation and decision-making in a custom-designed remodelling of her domestic space.

It is also noteworthy that this design practice was educational not only for the students who carried out such projects, but also for the participating homemakers themselves: engaging them so intensely both physically and mentally, the remodelling projects must have significantly developed the homemakers' spatial imagination and proprioception. In addition, the practice was likely to bring a boost of self-confidence to the homemaker who went through this process: assuming a form of intense exchange between the homemaker and the students, the practice blurred the rigid division between the 'client' and the 'designer team', and validated the homemaker as competent and indispensable contributor to improved design solutions for her space to the extent that turned her into a co-designer.

This dissolution of the rigid division between the user/client and designer highlights a crucial difference between home economists' and modernist design practices. Modernists not only imposed on the user but also tended to keep the client at arm's length and in effect took on an esoteric atmosphere from the client's perspective. Modernist architects who did not assume such an attitude and tried to admit the user to the planning process - like Gerrit Rietveld in his work on Schröder house (1923-4) and Heinrich Tessnow's work on Siedlung Hellerau (1908-09) - were exceptions. ${ }^{19}$ By contrast, home economists were not only inclusive towards the client, but heavily relied on her input by rule; in such a close dialogue-based dynamic the designer team did not have a chance to generate an aura of arcaneness in the client's perception. Thus, it can be said that the home economists' design practice demystified domestic interior design and made it egalitarian. The message it conveyed was that everybody who engages physically and mentally with her space is capable of coming up with solutions that will improve it.

\section{Feminist critique}

Although educating and empowering, the homemaker's engagement in the design process of her domestic work zones was also a way of reinforcing the conventional association of women with domesticity, a way of disciplining into a gender 


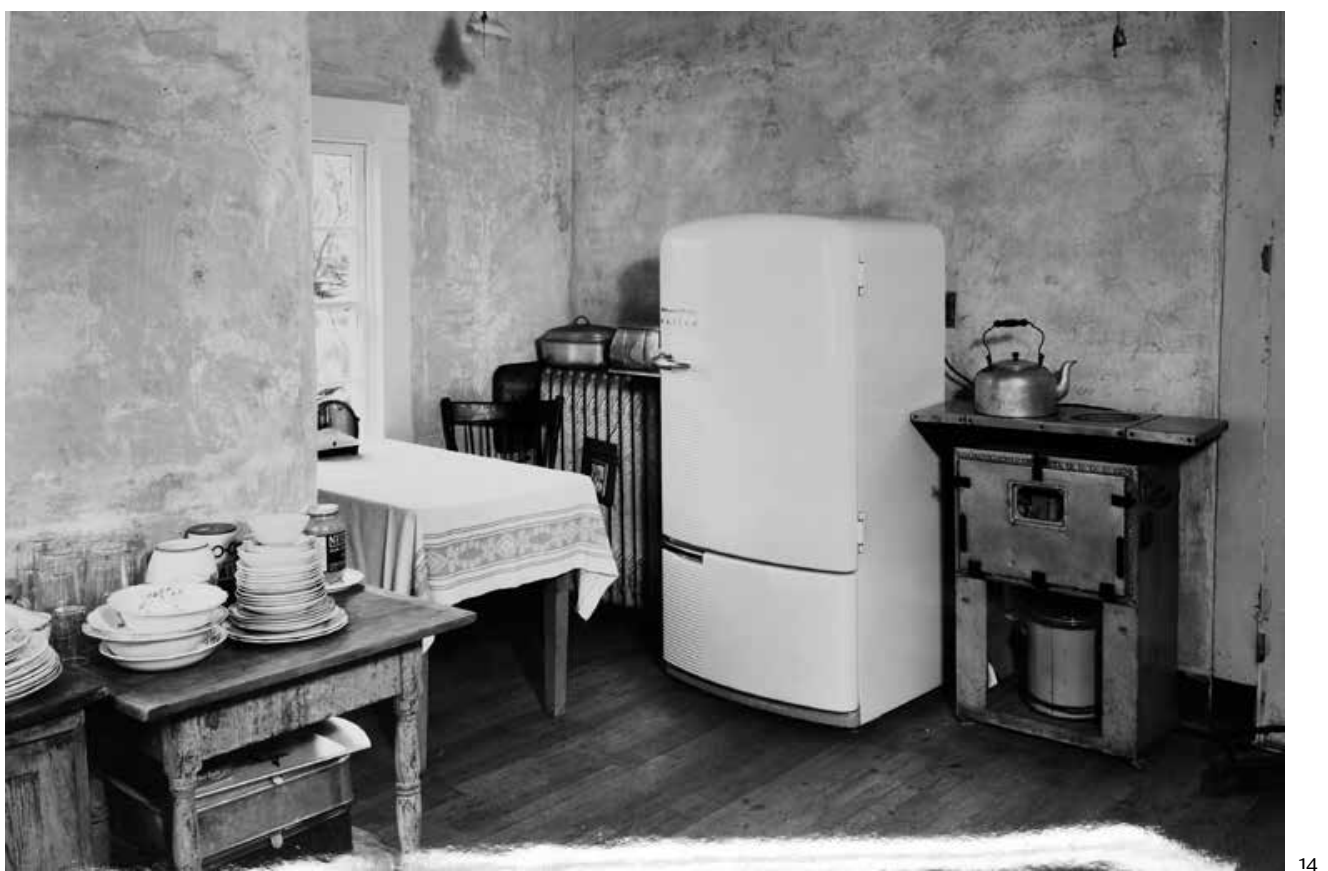

role. Subjecting the homemakers to the repeated 'walk-outs' in the model kitchens can be seen as sheer reiteration through which the patriarchal discourse enacts its effects, becomes performative, actively corroborates the notion of femaleness as intertwined with the domestic sphere. In spite of their unquestionably respectful attitude towards the women's preferences for her space, the Economics of the Household students carried out design practice that harnessed the homemakers' bodily and mental activities into the highly gendered notion of modern American woman.

One can argue that even though the home economists did not intend to manipulate the homemakers, their well-meant design practice was in fact a psychological operation with sociological and cultural implications. Drawing the homemakers into the design of their work spaces was likely to prompt them towards a process of emotional appropriating, personal attachment to these spaces: the spaces were their creations, in which they invested their time, and physical and mental efforts. Even if the homemaker did not enjoy her domestic duties, performing them in a space of her own creation likely made her feel better in this space, and pulled her towards a more accepting attitude towards housework itself. It prompted her to believe that she really does belong to the domestic realm, which solidified the traditional identification of women with the home. In other words, although the women were given the right to mould their space, their thorough participation in this process was also a vehicle through which the household was being mentally and physically inscribed into their (self)-identity.

\section{User-centred design and the aesthete homemaker}

The degree to which home economists were usercentred in their design practice becomes even more evident when one realises that, in spite of their

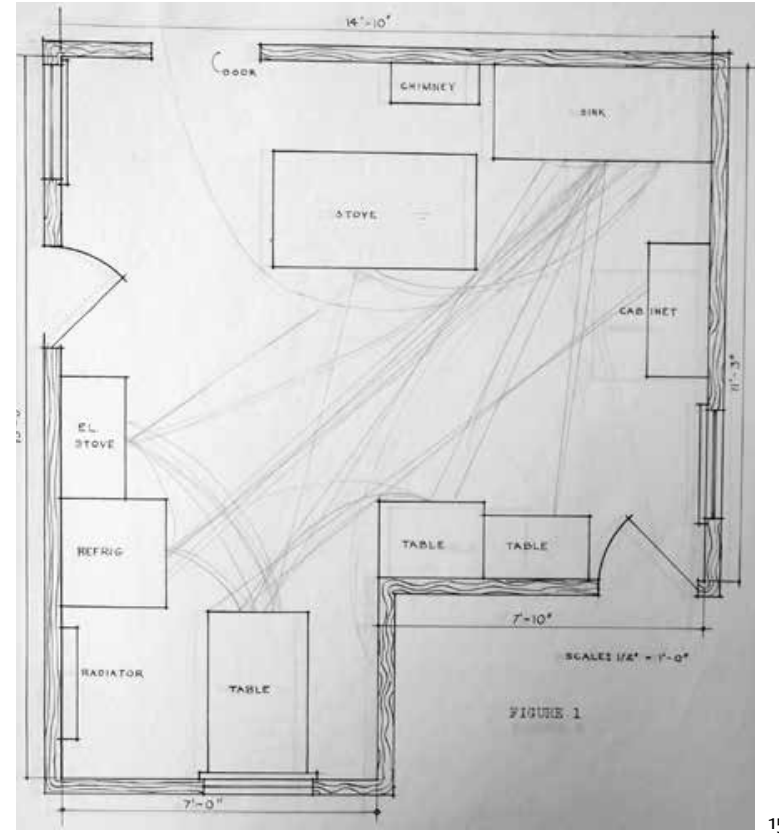

$\begin{array}{ll}15 \text { Plan of Mrs Farden's } & \text { Manuscript } \\ \text { kitchen before the } & \text { Collections, Cornell } \\ \text { remodelling. Dept. } & \text { University Library, } \\ \text { of Household } & \text { \#23-18-1648, Box 6, } \\ \text { Economics and } & \text { H.B., 'Dishes on } \\ \text { Management } & \text { Display', Term Paper } \\ \text { Research Studies, } & \text { for Ec HH 310, 17 } \\ \text { Division of Rare and } & \text { December 1947, p. 8. }\end{array}$

predilection for labour-saving and efficiencyimproving solutions, they were able to constrain their own design credo and engaged in projects even with those homemakers who wanted to make their homes more beautiful rather than easier to care for. The case of the collaboration between Cornell home economists and Mrs Farden on the latter's kitchen in 1947 leaves no doubt that home economists were not only open to working with homemakers who were mainly aesthetically oriented in their remodelling 


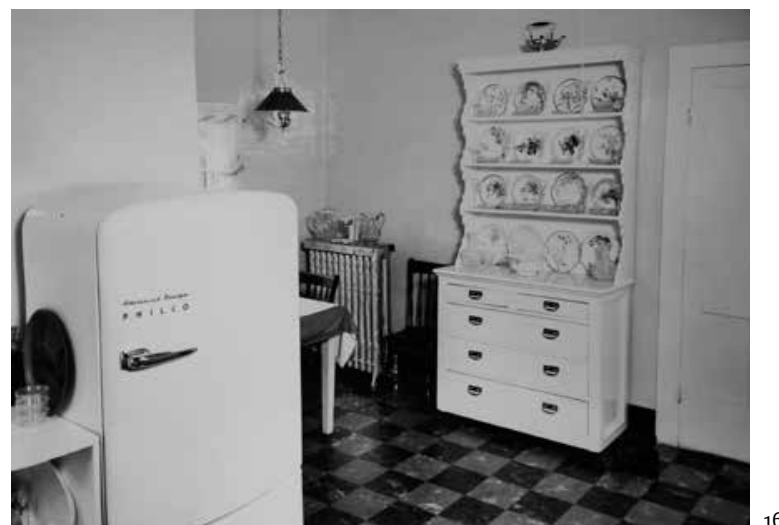

16 Mrs Farden's kitchen after the remodelling. Dutch cupboard found its place in the location where Mrs Farden wanted to put it: in the area of the breakfast table, where the fridge used to be $[15,17]$. As in the cupboard above the sink, the plates rested against the shelves' backs with frontal sides in view, her

preferred

arrangement. Dept. of Household Economics and Management Research Studies,

Division of Rare and Manuscript

Collections, Cornell

University Library,

\#23-18-1648, Box 6 .

17 Mrs Farden's kitchen
before the
remodelling.
Breakfast table nook.
Dept. of Household
Economics and
Management
Research Studies,
Division of Rare and
Manuscript
Collections, Cornell
University Library,
\#23-18-1648, Box6.

18 Mrs Farden's kitchen after the remodelling. Breakfast table nook with the Dutch cupboard. What was crucial to the homemaker, her 'company dishes' were finally granted a proper space, in which they could be both admired and, if she had wanted, easily used at the table. Dept. of Household Economics and Management Research Studies, Division of Rare and Manuscript Collections, Cornel University Library, \#23-18-1648, Box 6.
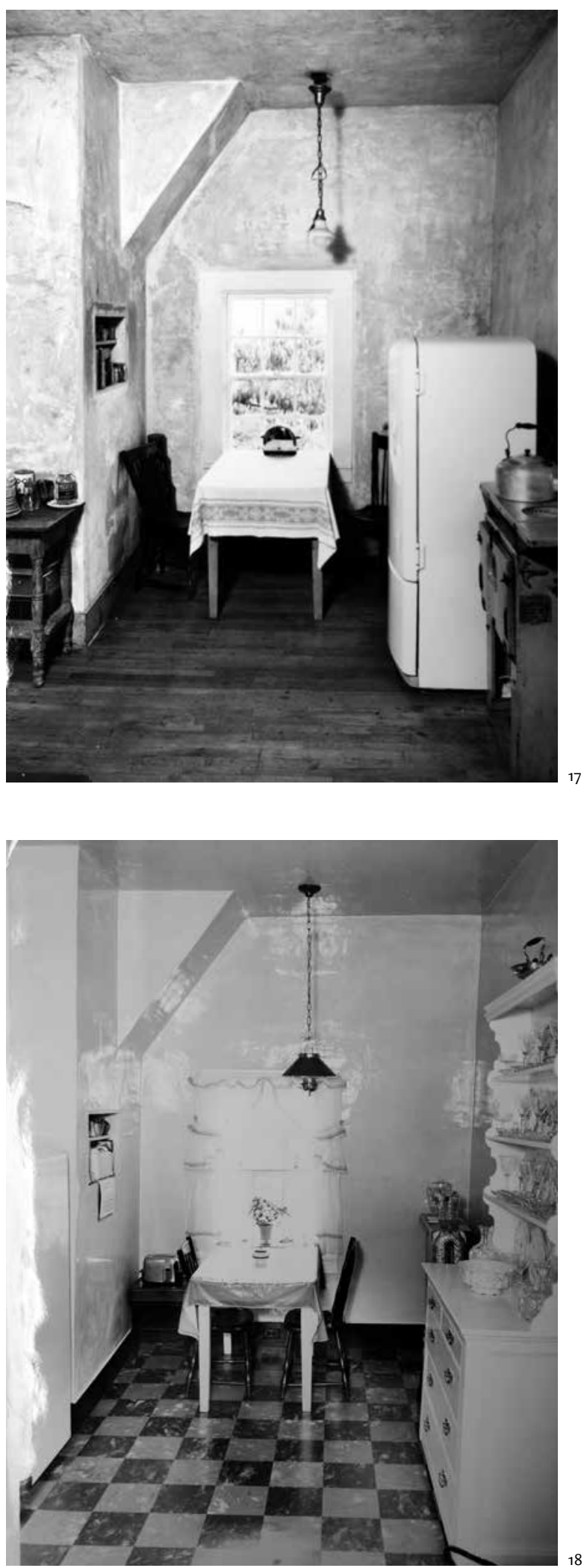

It is revealing to analyse the way Mrs Farden and the Cornell home economists carried out the project and negotiated their approaches. Mrs Farden's approach was appearance-oriented: to her the interior was expected to 'look good' and visually match a traditional, American, though not very clearly defined, style. By contrast, the home economists sought their usual: a compact, labourand step-saving arrangement. The divergence quickly became evident. When designing a dish cupboard practical space in the spirit of the home economists' design principles. 


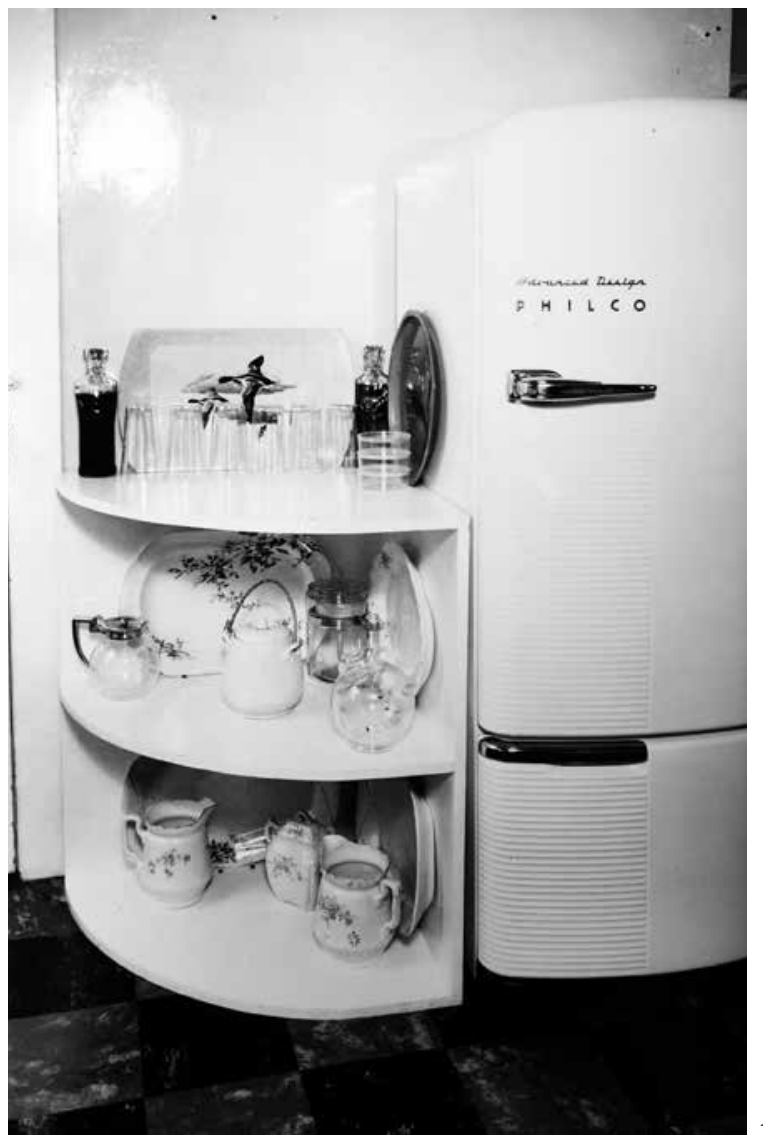

$$
\begin{aligned}
& 19 \text { Mrs Farden's kitchen } \\
& \text { after the } \\
& \text { remodelling. Another } \\
& \text { dish display area. } \\
& \text { Dept. of Household } \\
& \text { Economics and } \\
& \text { Management } \\
& \text { Research Studies, } \\
& \text { Division of Rare and } \\
& \text { Manuscript } \\
& \text { Collections, Cornell } \\
& \text { University Library, } \\
& \text { \#23-18-1648, Box 6. }
\end{aligned}
$$

above the sink, the home economists suggested a system that served the economy of space: file racks and step shelves. This idea did not appeal to Mrs Farden at all. Instead of the files that would hide the dishes, she wanted a traditional display arrangement: lining them with frontal sides exposed so that they would rest against the shelves' back. One of the students argued that the file-and-shelf system could be very attractive to the eye and invited Mrs Farden to see a successful example of it in the cottage where she resided that term. Mrs Farden was still adamant that she did not want files as it interfered with her wish to display her dish collection as much as possible. ${ }^{21}$ The students conceded and submitted to Mrs Farden's wish: the project's next stage revolved around designing the cabinets so that the dish collection would be on display.

Eventually, Mrs Farden could enjoy no less than three completed areas of dish display in her kitchen. As it was the case with the cupboard above the sink, a Dutch cupboard was a result of her wishes as well, both in terms of appearance and location in the area of breakfast table $\left[15^{-18}\right] .{ }^{22}$ For this cupboard she designed the shelves herself so that they fit the dishes she chose for this spot. As a whole, with an old dresser used as its base and the traditional decoration on the edges of its upper sides, the cupboard matched the house's traditional, quaint character that Mrs Farden liked and wanted to enhance.

Overall, Mrs Farden had reasons to be pleased with the remodelling of the breakfast nook. Comparing the nook before and after remodelling, one can easily argue that the project brought an improvement. The access to the breakfast table was facilitated: unlike the fridge in the previous arrangement, the Dutch cupboard did not protrude into the path to the table and did not obstruct the passage. Visually, there was an upgrade too: unlike the chunky, domineering volume of the fridge that overburdened the area, the cupboard gently enlivened the nook through its inherent decorative elements and the dishes and glassware on view $[\mathbf{1 7}$, 18]. Given Mrs Farden's interest in traditional aesthetics and entertaining, the nook must have been a radical improvement: it both looked and functioned much better, and became a more inviting space, suggesting unhurried hospitality $[18,19]$.

It should be mentioned, however, that home economists working with homemakers-aesthetes, such as Mrs Farden, were not merely catering to the homemakers' wants. During the process of devising the new layouts they did encourage the women to account for a greater 'convenience' of work in the kitchen design. Yet, whenever there was a difference of opinions, they were giving in to the homemaker's preference. The homemaker's concern for appearance at the expense of convenience was not a reason for the home economists to withdraw from the project. The ultimate test of the successful new design was for the home economists the user's 'fit' understood as the user's satisfaction.

\section{Crossing paths with Taylorism and transcending it}

Advocating the economy of movement and physical effort through compact space arrangements aiming to simplify and minimise labour, home economists shared traits with Taylorism, the theory of scientific management intending to increase output in factories, developed by Frederic W. Taylor at the end of the nineteenth century in the US. Both home economists and Taylorists not only embraced the concept of efficiency, but also looked for it through the exploration of time and effort-saving methods of performing physical tasks.

But while there were home economists, like Christine Frederick, who argued for applying Taylorism to the domestic setting, other home economists expressed their strong reservations to the idea, pointing out that pivotal differences between factory and domestic environments undermined the adaptability of scientific management organisation to the home. One of the differences their underscored was the divergence of ultimate goals between the two environments: maximum output in the factory versus the contentment of family members, in particular the individual homemaker, in the home. ${ }^{23}$ 
In contrast to the realities of industry, home economists - as the case studies discussed earlier demonstrate - usually regarded efficiency and greater productivity as just a means whose employability was held in check by the individual homemaker's preferences and satisfaction, verified at various stages of the participatory design process. It is also noteworthy that Taylorism cannot even be credited with instigating the home economists' approach to domestic design, for the reformers' linking the economy of movement and labour with compact work spaces had a precedent long before Taylorism emerged, in the mid-nineteenth-century American domestic advice: Catherine E. Beecher and Harriet Beecher Stowe's The American Woman's Home (1869). At least one reason for which American home economics has often been seen merely as an adaptation of Taylorism to the home is likely the popularity of Christine Frederick's writings explicitly endorsing scientific management as a model for domestic design.

Translated by Irene M. Witte and published in German in the 1920s, Fredrick's writings became influential among European avant-garde designers and contributed to the impact of scientific management on modernist architecture, including domestic design. Two kitchen floor plans marked with the homemaker's travel lines used by Frederick in her The New Housekeeping: Efficiency Studies in Home Management (1913, original English edition, 1921, German edition) to illustrate the contrast between an efficient and inefficient furniture and equipment arrangements were reproduced in Bruno Taut's Die neue Wohnung: Die Frau als Schöpferin (The New Dwelling: The Woman as Creator) (1924) and her New Housekeeping had a direct influence on Margarete SchütteLihotzky when the latter worked on her Frankfurt Kitchen (1926). ${ }^{24}$

While Frederick's focus on transferring scientific management to the domestic realm did not grant the individual homemaker a role in design that would be as active as in the above-discussed and many other examples of the home economists' design practice, the modernist interpretation of Frederick's work suppressed further the specific homemaker's impact on the design of her kitchen space. For example, whereas Frederick's The New Housekeeping still argued for kitchens adjusted to the individual features of their users, for example the height of kitchen countertops was to account for the user's height, the Frankfurt Kitchen was a factoryassembled unit brought to the designated place with the aid of crane. ${ }^{25}$ While Frederick conceptualised the domestic interior as accounting for the variability of homemakers, the Frankfurt Kitchen was for a generic user, the woman. ${ }^{26}$

The practice of marking the dwellers' travels on the interior's floor plan proved to lend itself to convey very differing ends and conceptions of the user-design relationship. While Cornell home economists used it as a means in a process aiming to help a specific homemaker arrive at a design that suited her preferences, many mainstream modernist designers saw or drew such pathways primarily as an expression of their view how the user should use the space, move in it, and even perceive it, and ultimately as 'objective' proof validating their spatial solutions. This latter approach was present, for example, in Alexander Klein's use of graphical method that included marking trajectories of movement on floor plans. Assuming a notion of the inhabitant that was at once very generalised and at the same time infused with the architect's vision of his or her dwelling 'needs', Klein employed the language of marked pathways to argue for the superiority of his floor plans over those of other architects. ${ }^{27}$

Klein's use of the travel diagrams for the purpose of validation reveals a deeper link between mainstream modernist architects and scientific management. To Klein and others at the turn of the twentieth century, mapping movement connoted objectivity espoused by Taylorism. ${ }^{28}$ But the appeal of scientific management exceeded the issue of objectivity alone. For Klein, as for many other modernists, scientific management with its emphasis on order was an ideology that reinforced and legitimised their position as organisers of reality, technocrats empowered by their expert and seemingly objective and neutral - knowledge. ${ }^{29}$ Armoured with this self-image, they felt unsurprisingly competent to know what people need and design accordingly to this vision.

\section{Conclusion}

It is noteworthy that entailing such a close, direct collaboration with the user, engaging her both physically and mentally in experimenting with fullscale models, home economists not only devised a valid method of participatory design before the movement of participation of the 1960s and 1970s, but also fulfilled the movement of participation's call to dismantle the traditional notion of architectural authorship. The corollary of the home economists' intense focus on the user in their design practice is the projects' lack of an individual designer-derived, authorial, signature stamp other than that coming from the user-co-designer herself. Many of the practice's examples feature at least some aspects of the home economists' efficient, labour-easing conception of domestic space, but I found no evidence of any home economist attempting to treat the project as a vehicle to fulfil her personal vision. Unlike many modernist architect-client relationships, such as the earlierreferenced one between Farnsworth and Mies, the home economists' design practice was not about the designer. Rather, like the movement of participation advocated years later, it dissolved the clear distinction between the designer and the user. 


\section{Notes}

1. Giancarlo De Carlo, 'Architecture's Public', in Architecture and Participation, ed. by Peter Blundell Jones, Doina Petrescu, Jeremy Till (London and New York: Spoon Press, Taylor \& Francis Group, 2005), pp. 3-22 (pp. 13, 15-17).

2. Ibid., p. 17.

3. Wolfgang F. E. Preiser, Harvey Z. Rabinowitz, Edward T. White, PostOccupancy Evaluation (New York: Van Nostrand Reinhold Company, 1988), pp. 3,8

4. Peter Bycroft and Kirsty McGregor, 'Post-Occupancy Evaluation (POE) and Sustainable Design', in Environment Design Guide (Royal Australian Institute of Architects: 2002), pp. 1-8 (pp. 3-4).

5. Preiser, Rabinowitz, White, PostOccupancy Evaluation, pp. ix, 3.

6. Tatjana Schneider and Jeremy Till, Flexible Housing (Amsterdam, Boston, [etc.]: Elsevier, 2007), p. 99; Niall Patrick Walsh, '6 Radical Experiments in Social Housing Exhibited by the RIBA and V\&A', ArchDaily (15 November 2018)<https:/www.archdaily. com/905948/6-radical-experimentsin-social-housing-exhibited-by-theriba-and-v-and-a $>$ [accessed 5 March 2021].

7. Mats Egelius, 'The Byker Wall', in Housing and Dwelling: Perspectives on Modern Domestic Architecture, ed. by Barbara Miller Lane (London and New York: Routledge, Taylor \& Francis Group, 2007), pp. 323-6 (pp. 323-4)

8. Carolyn M. Goldstein, Creating Consumers: Home Economics in Twentieth-Century America (Chapel Hill, NC: The University of North Carolina Press, 2012); Rethinking Home Economics: Women and the History of a Profession, ed. by Sarah Stage and Virginia B. Vincenti (Ithaca, NY and London: Cornell University Press, 1997).

9. Dolores Hayden, The Grand Domestic Revolution (Cambridge, MA and London, UK: The MIT Press, 1982), pp. 69, 79-81, 119, 171-4. 10. Ella M. Cushman, 'Fit Your Kitchen to Your Space', Farm Journal, 73:712 (October 1949), pp. 139-40 (p. 140).

11. Dept. of Household Economics and Management Research Studies, Division of Rare and Manuscript Collections, Cornell University Library, \#23-18-1648, Box 6, N.B., Term Paper for E.H. 310, 20 December 1950, p. 1.

12. Dept. of Household Economics and Management Research
Studies, Division of Rare and Manuscript Collections, Cornell University Library, \#23-18-1648, Box 6, D.J., Term Paper for E.H. 310, 20 December 1950, p. 13.

13. N.B., Term Paper for E.H. 310, p. 13

14. Ibid, p. 17.

15. Alice T. Friedman, 'People Who Live in Glass Houses: Edith Farnsworth, Ludwig Mies van der Rohe, and Philip Johnson', in Alice. T. Friedman, Women and the Making of the Modern House: A Social and Architectural History (New

Haven, CT and London: Yale University Press, 2006), pp. 127-59 (pp. 134-43)

16. Leslie Land, 'Counterintuitive: How the Marketing of Modernism Hijacked the Kitchen Stove', in From Betty Crocker to Feminist Food Studies: Critical Perspectives on Women and Food, ed. by Arlene Voski Avakian and Barbara Hakian (Amherst \& Boston, MA: University of Massachusetts Press, 2005), pp. 41-61 (p. 44).

17. N.B., Term Paper for E.H. 310 pp. 17-18.

18. Ibid., p. 28

19. Alice T. Friedman, 'Family Matters: The Schröder House, by Gerrit Rietveld and Truus Schröder', in Friedman, Women and the Making of the Modern House, pp. 64-92; Susan R. Henderson, Building Culture: Ernst May and the Frankfurt am Main Initiative, 1926-31 (New York: Peter Lang Inc., International Academic Publishers, 2013), p. 153.

20. Dept. of Household Economics and Management Research Studies, Division of Rare and Manuscript Collections, Cornell University Library, \#23-18-1648, Box 6, H.B., 'Dishes on Display', Term Paper for E.H. 310, 17 December 1947 , pp. 2-4.

21. Ibid., pp. 16-17.

22. Ibid., pp. 6-7.

23. Ella Cushman, 'Organization of the Sewing Centre in the Home' (unpublished Master's thesis, Cornell University, 1928), p. 4

24. Tanja Scheffler, 'Margarete Schütte-Lihotzky: Küche, Kinder, Kommunismus/Children, Kitchen, Communism', in Frau Architekt: Over 100 Years of Women in Architecture, ed. by Mary Pepchinski, Christina Budde, Wolfgang Voigt Peter Cachola Schmal (Berlin, Deutsches Architekturmuseum, Frankfurt am Main \& Ernst Wasmuth Verlag Tubingen: 2017), pp. 123-31 (p. 126).

25. Susan R. Henderson, 'A Revolution in the Woman's Sphere: Grete
Lihotzky and the Frankfurt Kitchen', in Architecture and Feminism, ed. by Debra Coleman, Elizabeth Danze, Carol Henderson (New York: Princeton Architectural Press, 1996), pp. 221-54 (p. 236-7).

26. Leif Jerram, 'Kitchen Sink

Dramas: Women, Modernity, and Space in Weimar Germany', Cultural Geographies, 13:4 (October 2006), pp. 538-56 (p. 551).

27. Christoph Lueder, 'Evaluator, Choreographer, Ideologue, Catalyst: The Disparate Reception Histories of Alexander Klein's Graphical Method', Journal of the Society of Architectural Historians, 76:1 (March 2017), pp. 82-106 (pp. 82, 85, 93, 95).

28. Ibid., p. 89

29. Mauro F. Guillén, The Taylorized Beauty of the Mechanical: Scientific Management and the Rise of Modernist Architecture (Princeton, NJ and Oxford, UK: Princeton University Press: 2009), p. 4.

\section{Illustration credits}

arq gratefully acknowledges: Cornell University Library, all images

\section{Acknowledgments}

This article draws on a chapter of my $\mathrm{PhD}$ dissertation. I would like to thank Swati Chattopadhyay for her generous advice, Eileen Keating and Hilary Dorsch Wong for their kind and professional assistance during my research at Cornell University, Juliet Odgers, Laurent Stalder, and two anonymous reviewers for their comments that helped me improve the article, and Philip Ursprung for his postdoctoral supervision. I acknowledge the financial support of the 2015 Cornell University Dean's Fellowship in the History of Home Economics.

\section{Competing interests}

The author declares none.

\section{Author's biography}

Following her $2018 \mathrm{PhD}$ in the History of Art and Architecture at the University of California, Santa Barbara, Anna Myjak-Pycia is a postdoctoral scholar at the Institute for the History and Theory of Architecture (gta), at the ETH Zürich. Her interests focus on user-oriented design and the history of domestic interiors.

\section{Author's address}

Anna Myjak-Pycia

anna.myjak@gta.arch.ethz.ch 